\title{
EL GOBIERNO DE DOÑA VIOLETA DE CHAMORRO: LA CONSTRUCCIÓN DE UN MITO POLÍTICO-IDEOLÓGICO VERSUS LA REALIDAD ECONÓMICA SOCIAL
}

Guillermo Fernández Ampié

\section{Resumen}

Este ensayo ofrece un análisis crítico de tres textos referidos a la ex presidenta Violeta de Chamorro, escritos y publicados en diferentes momentos de las últimas dos décadas por funcionarios de su gobierno y su círculo familiar. Estos textos son: Imágenes de cambio, un lujoso volumen con abundantes fotografías publicado en los últimos meses de su gestión para divulgar las obras realizadas por el gobierno de Chamorro en diferentes ámbitos de la vida del país; La difícil transición nicaragüense, escrito por Antonio Lacayo, ministro de la Presidencia de la señora Chamorro y publicado en el 2006; y La democracia de Pedro y presidenta Violeta B. de Chamorro, editado por Cristiana Chamorro, hija de la expresidenta y publicado en 2013. Estas publicaciones, se argumentará, pretenden conferir a la figura de la señora de Chamorro un "aura mítica" y transformar su gobierno en un mito político-ideológico. Al contrastar las interpretaciones que ofrecen las obras en cuestión con los hechos y cifras que reflejan lo que significó dicho gobierno en términos socioeconómicos para la mayoría de la población, el ensayo se propone además demostrar que tal mito tiene pies de barros y que, como el emperador del famoso cuento danés, también camina sin vestidos.

Palabras claves: Gestión de gobierno, transición política, mito político, textos publicitarios

\section{Abstract}

This essay offers a critical analysis of three books published in the last twenty years about Violeta Chamorro's government, written by government officials and members of her family: Imágenes de cambio, a luxury volume filled with photographs, published in the last few months of Chamorro's administration to disseminate her goverment's achievements in different aspects of Nicaraguan life; La difícil transición nicaragüense, by Antonio Lacayo, Chamorro's Minister of the Presidency (2006); and La democracia de Pedro y presidenta Violeta B. de Chamorro, edited by Cristiana Chamorro, daughter of the former president.

This paper argues that those books attempt to construct a "mystical aura" around Violeta Chamorro and turn her government into a political and ideological myth. The article contrasts the interpretations offered by these books with facts and figures that show the real consequences of the Chamorro government's economic policies for most of the Nicaraguan population. It aims to show that this political myth lacks a solid foundation: like the emperor in the famous Danish children's story, it has no clothes.

Keywoords: governance, political transition, political mith, advertising text 
Este ensayo ofrece un análisis crítico de tres textos referidos a la ex presidenta Violeta de Chamorro, escritos y publicados en diferentes momentos de las últimas dos décadas por funcionarios de su gobierno y su círculo familiar. Estos textos son: Imágenes de cambio, un lujoso volumen con abundantes fotografías publicado en los últimos meses de su gestión para divulgar las obras realizadas por el gobierno de Chamorro en diferentes ámbitos de la vida del país; La difícil transición nicaragüense, escrito por Antonio Lacayo, ministro de la Presidencia de la señora Chamorro y publicado en el 2006; y $L a$ democracia de Pedro y presidenta Violeta B. de Chamorro, editado por Cristiana Chamorro, hija de la expresidenta y publicado en 2013. Estas publicaciones, se argumentará, pretenden conferir a la figura de la señora de Chamorro un "aura mítica" y transformar su gobierno en un mito político-ideológico.

$\mathrm{Al}$ contrastar las interpretaciones que ofrecen las obras en cuestión con los hechos y cifras que reflejan lo que significó dicho gobierno en términos socioeconómicos para la mayoría de la población, el ensayo se propone demostrar que tal mito tiene pies de barros y que, como el emperador del famoso cuento danés, también camina sin vestidos.

El discurso más difundido sobre la transición y la democratización de Nicaragua, reiterado constantemente por los principales medios de comunicación extranjeros y los nacionales vinculados a la clase empresarial antisandinista, sostiene que con el triunfo electoral y la toma de posesión de Violeta Barrios de Chamorro como presidenta del país, en 1990, inició o llegó la democracia en Nicaragua. Este discurso agrega además, que dicho proceso de democratización estaría caracterizado por la pacificación del país con la conclusión de la guerra que afectaba al país durante casi una década-, haber logrado la reconciliación de los bandos políticos enfrentados, y el restablecimiento de las libertades públicas -principalmente de expresión y prensa-, la apertura del libre mercado y la estabilidad económica. Este relato, que también significa la interpretación y una versión de la historia reciente del país, también ha sido inculcado a las nuevas generaciones de nicaragüenses a través de los textos escolares.

Nuestro trabajo no pretende refutar ninguno de esos asertos, sino colocarlos en un contexto más amplio y desde la perspectiva de los sectores mayoritarios de la población, exponiendo las limitaciones y contradicciones de dicha narrativa. Al hacer esto, nuestro interés es ofrecer elementos que contribuyan a conocer y elaborar una versión de nuestra historia reciente que problematice y exprese, con mayor claridad, la complejidad de ese momento histórico vivido por los nicaragüenses.

En un texto en el que analiza los discursos hegemónicos sobre las llamadas transiciones a la democracia en América Latina, Gustavo Ogarrio llama la atención sobre el hecho de que en esos relatos también resultan evidente determinados "olvidos" así como la ausencia de referencias a la dominación y la explotación que han sufrido, y aún sufren, los sectores subalternos de la población. ${ }^{1}$

Refiriéndose a estos olvidos, Ogarrio señala que "una de las mayores dificultades enfrentadas por el poder surgido con las transiciones democráticas en América, se encuentra en el modo en que asimilaron e interpretaron la época anterior inmediata...". ${ }^{2}$ De esta manera, sostiene, los procesos de transición han impuesto una especie de olvido obligado, especialmente sobre las políticas de secuestros, asesinatos extrajudiciales y desaparición de personas, practicadas como políticas de Estado por las dictaduras militares.

1 Ogarrio Badillo, Gustavo, Breve historia de la transición y el olvido. Una lectura de la democratización en América Latina. México: Ediciones EON y CIALC-UNAM, 2012.

2 Ibídem, p. 115. 
El académico mexicano se refiere particularmente a los procesos de transición en el cono sur, pero su planteamiento resulta útil para preguntarse qué olvidos promueve y que versión de la historia reciente de Nicaragua construye el discurso hegemónico sobre el gobierno de Violeta de Chamorro y la llamada transición democrática nicaragüense. En este sentido es posible establecer un paralelismo entre "la política del dominio del olvido" impulsada por los gobiernos de la transición en Argentina -los de Carlos Menem y Raúl Alfonsín- con respecto a los crímenes cometido por la dictadura de los militares golpistas que señala Ogarrio, y la política del olvido promovida por ese discurso hegemónico sobre la transición nicaragüense al que hemos hecho referencia, en relación a las políticas sociales impulsadas por el gobierno sandinista y abortadas por la guerra contrarrevolucionaria que financió el gobierno estadounidense. Como veremos más adelante, este olvido, tiene a su vez un complemento: la decisión política de ignorar o subestimar las consecuencias sociales derivadas del plan de reestructuración y ajuste económicos impulsado por Chamorro y sus asesores.

Las poco más de dos décadas transcurridas desde la derrota electoral del FSLN en 1990 y los casi veinte años de concluido el período gubernamental de la señora Chamorro, si bien constituyen un corto periodo, permiten observar con mayor serenidad y en retrospectiva las múltiples caras de la llamada transición nicaragüense y la gestión de Chamorro y su equipo de gobierno.

De esta manera, aproximarnos a la versión de la historia de ese período ofrecida por personajes que entonces detentaban importantes funcionarios de gobierno es en verdad revelador, pues refleja la visión que este grupo político tiene de sí mismo. En un detenido análisis resultan evidentes dos elementos: el primero es que la transición a la democracia se presenta como si se tratara de algún milagro, como un acto de magia generado a partir de la victoria electoral y posterior toma de posesión de Chamorro; y no como un proceso mucho más complejo cuyas raíces podrían incluso ubicarse en 1979, cuando fue derrocado el dictador Somoza. ${ }^{3}$ La democracia misma, que por lo general casi nunca es definida, se convierte en una entelequia, como algo ya acabado, absoluto, que llegó o se instaló ahí, también, sólo por el mero hecho de que la señora Chamorro resultó electa como presidenta del país.

El otro elemento notable es que este discurso, y la interpretación de la historia que conlleva, además de promover los olvidos a los que aludimos, también se empeña en conferirle a la expresidenta Chamorro cierta aura mítica, o bien transformar su figura y a su gobierno en una especie de mito-político ideológico, de tal suerte que se les coloca por encima del bien y del mal, de la derecha y la izquierda, de los ricos y los pobres, como veremos a continuación.

\section{Las imágenes del discurso hegemónico acerca de la transición}

Al margen de estudios académicos de mayor rigor, ${ }^{4}$ uno de los primeros textos que ensalzaba la labor realizada por la señora Chamorro fue el volumen titulado Transición y Transformación. 1990-1996 imágenes del

3 A diferencia del discurso sobre la transición nicaragüense más publicitados, Joan Font y Ricard Gomá consideran que el proceso de democratización nicaragüense inició en 1979, precisamente con el derrocamiento del dictador Somoza Debayle. Estos autores además señalan distintas fases de este proceso: 1979-1984, 1984-1987 y 1990 en adelante, que consideran como el periodo de consolidación democrática. Ver su artículo "El proceso de democratización en Nicaragua: actores, estrategias y conflictos", en Revista CIDOB d'Afers Internacionals.

Disponible en: http://www.raco.cat/index.php/revistacidob/article/viewFile/27849/51977

Fecha de consulta: 8 de enero de 2015.

Jorge Rovira Más también coincide con esta interpretación. Ver “Nicaragua 1979-2007. Transición a la democracia y perspectivas de su consolidación". Revista Encuentro No. 82 (2009), pp. 6-24. Fecha de consulta: 13 de enero de 2015.

4 Ver por ejemplo el trabajo de Rovira Más, "Transición a la democracia y su consolidación en Centroamérica: Un enfoque para su análisis", en Anuario de Estudios Centroamericanos, No. 1-2, Vol. 2 (2002), pp. 9-56. 
cambio, editado por Pedro Joaquín Chamorro Barrios, hijo de la presidenta Chamorro. Publicado con fondos gubernamentales, consta principalmente de numerosas fotografías, la mayor parte de ella a colores, con sus respectivas leyendas. Un proverbio chino explica su forma y propósito: "más vale ver una vez que oír cien veces". La idea que parece prevalecer en sus páginas es la de contrastar, utilizando una gran cantidad de imágenes, una versión muy particular, además de sesgada, de la vida cotidiana durante los años de gobierno sandinista y el supuesto progreso económico-material que habría alcanzado Nicaragua durante el mandato de la señora Chamorro.

El volumen abunda, por ejemplo, en fotografías de numerosos negocios tanto extranjeros como nacionales, instalados en diversas localidades nicaragüenses entre 1990 y 1996. En ellas pueden observarse filiales de las cadenas de comida rápida estadounidenses Pizza Hut y Subway, o de la distribuidora de automóviles Chevrolet, así como de estaciones de gasolina y tiendas de autoservicio filiales de las transnacionales Texaco, Shell y Esso. La leyenda que acompaña estas fotos señala que las grandes cadenas transnacionales han hecho inversiones que colocan a estas estaciones como las mejores del mundo "dando a los usuarios un servicio que antes no se soñaba en Nicaragua". ${ }^{5}$

En otras de las gráficas pueden observarse anuncios espectaculares de diversos comercios junto a carteles de publicidad partidaria. De igual manera se contemplan imágenes de los juzgados durante el gobierno sandinista, normalmente localizados en casas populares, vale decir elaboradas de adobe y con techo de tejas, contrastados con las edificaciones modernas construidas posteriormente. La leyenda en las primeras fotos anuncia: "Rótulos comerciales gigantes se mezclan indistintamente con la propaganda política electoral... Este es un síntoma inequívoco de que la reactivación económica ha comenzado y que va de la mano con el pluralismo político". ${ }^{6}$

Otras imágenes que merecen ser comentadas son las de numerosas fílas de personas que esperan ser atendidas en los centros de distribución de alimentos básicos establecidos por el gobierno sandinista; filas ciertamente comunes en los años revolucionarios. También se observa la estantería de supermercados en manos del estado, en los años ochenta, en general vacías, en violento contraste con la abundancia de productos que se exhiben en los mismos supermercados una vez privatizados o regresados a sus antiguos propietarios. El contraste resulta aún más fuerte por cuanto en las fotografías de la época sandinista aparecen en blanco y negro, en tanto que las del periodo del gobierno de Chamorro se publican a todo color, lo cual produce un impacto que recuerda el contraste causado por un efecto similar, se me perdonará la referencia, por la película $E l$ Mago de Oz, de 1939.

En cuanto a los olvidos $\mathrm{u}$ omisiones que promueven estas fotografías y sus leyendas, debe señalarse en primer lugar que se cuidan mucho de revelar que fue un sector de la población nicaragüense, más bien restringido, la que tuvo acceso a ese "progreso" y dichos bienes de consumo, en especial en el caso de las tiendas de auto-servicio y los restaurantes de comida rápida. En cuanto a las filas, al no ofrecer ninguna otra información o explicación que contextualice las mismas, se oculta que tanto la guerra de agresión como el bloqueo económico que sufrió el país en esos años eran factores estrechamente vinculados con la escasez de alimentos. Tampoco se señala que la política de cuotas o

5 Chamorro Barrios, Pedro Joaquín (Edit.)., Transición y transformación. 1990-1996. Imágenes del cambio. Managua: Gobierno de Nicaragua y Editorial El Amanecer, 1996, p. 36.

6 Ibídem, p. 26 
racionamiento de granos básicos tenía entre sus propósitos garantizar su distribución y consumo entre el mayor número de personas si acaso no a toda la población. Mucho menos indica que en el período en que los estantes de los supermercados en manos privadas rebosan de productos, el desempleo alcanzó una cifra récord que rondó el $60 \%$ de la población, ${ }^{7}$ que obviamente se vio excluida de acceder a tan tentadores productos.

En lo que respecta a los rótulos gigantes y las casas antiguas y nuevas de los juzgados y las leyendas que las acompañan, pueden hacerse dos comentarios. En la primera, la celebración de los anuncios publicitarios gigante no toma en consideración el impacto que tienen en el medioambiente y en la modificación negativa del paisaje. En las segundas, referidas a los juzgados, en las que se promueven los nuevos edificios como prueba del fortalecimiento del poder judicial, revelan una pobre concepción de la impartición de la justicia, pues limita el fortalecimiento de esta a un local físico y no a una mejor preparación o la integridad de los jueces.

Pero la fotografía que mejor revela la concepción de la democracia que comenzó a imperar en Nicaragua a partir de 1990 es la fotografía con la que se celebra las actividades turísticas y deportivas impulsadas bajo el gobierno de la señora Chamorro. En ella se observa al propio Pedro J. Chamorro, editor del volumen e hijo de la presidenta Violenta, y a varios de los miembros del gabinete de ésta, mientras navegan en un yate sobre las aguas del lago Cocibolca o de Nicaragua y se dedican a la pesca deportiva. ${ }^{8}$ Es una imagen que ilustra a la perfección el carácter elitista del gobierno de Chamorro y el nepotismo practicado también esos años. No falta decir que en Nicaragua son verdaderamente pocas las personas o familias que pueden darse el lujo de viajar en su propio yate.

\section{La versión oficialista, de la familia Chamorro, sobre la historia de este periodo}

Mucho mejor elaborado y de mayor peso resulta el texto escrito y publicado por Antonio Lacayo, yerno y ministro de la Presidencia en el gobierno de la señora Chamorro, considerado por muchos el hombre fuerte y verdadero poder detrás del trono. Su título es La difícil transición nicaragüense, y puede ser considerado como la versión oficial que posee la élite conservadora y neoliberal acerca de ese proceso, pues está contada desde el interior de quienes entonces gobernaron Nicaragua.

En ese volumen, Lacayo ofrece su versión de los objetivos que se habría propuesto la señora Chamorro al aceptar la candidatura que la convirtió en la primera mujer en la Presidencia de Nicaragua, explica o más bien justifica las diversas medidas políticas y económica tomadas durante los seis años del primer gobierno posrevolucionario, y ofrece sus concepción de la democracia y la idea de nación de este grupo, todo amenizado con llamativas anécdotas e infidencias.

Uno de los elementos que en mi opinión destacan en dicho texto es que tras insistir incontables veces que con la señora Chamorro llegó la democracia a Nicaragua, que su gobierno es democrático, que los ministros y funcionarios de ese gobierno son democráticos y que dejaron sentadas en el país las bases de una cultura democrática, en sus más de setecientas páginas apenas una sola vez, en unas cuantas líneas, expresa la

7 Cifra obtenida a partir de una encuesta realizada por la Fundación Internacional para el Desafío Global (FIDEG). Ver Renzi, María Rosa y Agurto, Sonia (edit.), ¿Qué hace la mujer nicaragüense ante la crisis económica? Managua: FIDEG, 1992. Cifra similar es utilizada por David Close en su obra Los años de doña Violeta. Historia de la transición política. Managua: Grupo Editorial Lea, 1995. La primera edición, publicada en inglés, es de 1999.

8 Ibídem, 137 y 138. 
concepción de democracia de su autor. Es una concepción que resulta particularmente vaga, difusa y escueta. Lacayo expresa que para él democracia básicamente es elegir autoridades por medio del voto, respetar a esas autoridades y respetar las leyes que rigen el país. ${ }^{9}$

Resulta igualmente notable que dicho volumen además de dar cuenta de la propia versión de ese período histórico, intenta establecer fijamente las siguientes ideas:

- Nicaragua se convirtió en un país democrático una vez que la señora Chamorro asumió la Presidencia, que además lo hizo como resultado de "las primera elecciones libres en la historia moderna del país"10.

- El gobierno sandinista, que por lo demás era una cruel dictadura, fue el responsable de la destrucción, la pobreza, del atraso y la crisis económica imperante en el país en el momento en que la señora Chamorro asumió la presidencia.

- El gobierno de la señora Chamorro comenzó a construir un país "para todos", su propia victoria electoral fue una victoria de "todos".

- Además, contribuye a la construcción de una imagen de Chamorro casi extraterrena, que encarna todas las buenas virtudes y que se encuentra por encima de toda ideología y sobre cualquier mezquindad o interés personal o político particular bajo.

Detengamos en algunos ejemplos de los tres primeros aspectos centrales de este discurso: En cuanto al primero, es la propia expresidenta Chamorro que deja establecida esta idea. En una breve nota introductora del texto, expresa: "Dejé una Nicaragua en paz, democrática y libre, con plena libertad de prensa, sin censuras ni amenazas". ${ }^{11}$ Esa idea, que también es presentada como la síntesis de todos los logros alcanzados por su gobierno, será remarcada con insistencia a lo largo de las setecientas páginas del volumen, de tal manera que los problemas que enfrenta y los errores que comete, que además casi no existen, se deben a que quienes conformaban ese gobierno "intentaban ser demócratas e imponer la democracia en una sociedad que no la conocía por culpa de las dictaduras somocista y sandinista". ${ }^{12}$ Esos problemas -tensiones con sus antiguos aliados de la Unión Nacional Opositora, el rearme de desmovilizados de la contra y del ejército sandinista, y las presiones ejercidas por funcionarios del gobierno estadounidense para que acelerara la "des-sandinización" del Estado, ponían en peligro "la Nicaragua democrática que teníamos desde 1990". ${ }^{13}$

Tal concepción del proceso de democratización, y la interpretación histórica que conlleva, no resiste un análisis de fondo. En primer lugar parte del supuesto de que la democracia se instaló en el país de un día para otro, aunque a lo largo de su relato reiterará que fue un proceso que experimentó muchas dificultades y complejidades. No obstante, la operación ideológica es dejar sentado que Nicaragua, desde 1990, comenzó a gozar de plena democracia, y que tal hecho es obra de la señora Chamorro y su equipo de gobierno.

Lacayo insistirá también en que todos los funcionarios del gobierno de Chamorro son democráticos per se, y constantemente se definirá como tal, reiterando a cada momento

9 Lacayo, Antonio, La difícil transición nicaragüense. En el gobierno con doña Violeta. Managua: Fundación Uno, 2006.

10 Ibídem, p. 27.

11 Ibídem, p. 7

12 Ibídem, p. 403.

13 Ibídem, p. 501. 
que los ministros de Chamorro eran "demócratas de convicción y de corazón". ${ }^{14}$ Pero nuevamente, tal definición de la democracia resulta superficial y débil. Afirma por ejemplo que "gobiernos democráticos como el nuestro sólo administran la ayuda (extranjera), no se quedan con ella". Insinuando que por su propia naturaleza en los gobiernos democráticos no existen casos de corrupción, cosa que resulta absurda cuando no ingenua. ${ }^{15}$

Una contradicción que escapa a Lacayo, y que refuta la caracterización que normalmente se hace de las fuerzas políticas nicaragüenses opositoras al sandinismo al tildarlas como democráticas, es que los conflictos más agudos, al extremo de poner verdaderamente en peligro la continuidad del gobierno de la señora Chamorro, fueron protagonizados precisamente por los líderes de los partidos políticos de la que fue candidata presidencial, y por los directivos del Consejo Superior de la Empresa Privada (Cosep).

Al referirse al conflicto que enfrentó con Alfredo César, entonces presidente del parlamento y antiguo miembro del directorio político de la contra, el propio Lacayo afirma que esa fue la principal conspiración que enfrentó el gobierno de la señora viuda de Chamorro. El entonces ministro de la presidencia afirma que se trató de una conspiración que además "incluía a Washington, al menos a la gente más radical de partido republicano... César quería provocar la renuncia de Chamorro para que asumiera (el vicepresidente Virgilio) Godoy". ${ }^{16}$ En otras palabras, quienes se llaman así mismo demócratas y que supuestamente habían promovido la democracia en Nicaragua, fueron quienes más se esforzaron por destruir al gobierno que desde 1990 representaba la democracia en Nicaragua. Lacayo no explica esa contradicción.

El ex ministro considera además que la suspensión de la ayuda económica comprometida por el gobierno estadounidense, medida política promovida por el senador Jesse Helms que acusaba a Chamorro y al propio Lacayo de cogobernar con los sandinistas, fue el acto más desestabilizador para todo el proceso democratizador, al cual se Alfredo César, ${ }^{17}$ su cuñado y presidente del parlamento nicaragüense.

Entre las afirmaciones e infidencias del ex ministro, también destaca su afirmación de que el Partido Social Demócrata, al que pertenecía César, había sido mantenido por el dinero que el presidente del Parlamento recibía de la Central de Inteligencia Americana durante su período como jefe político de la contra, hecho denunciado múltiples veces por el gobierno de Ortega y negado enfáticamente por los propios anti sandinistas y el diario La Prensa.

En este mismo orden, resulta igualmente revelador enterarse por Lacayo que la mayor resistencia, oposición y rechazo a todas las iniciativas de dialogo promovida por el gobierno de Chamorro, provinieron del sector empresarial, de manera que los representantes de la UNO y del Cosep resultan más intransigentes, radicales y menos demócratas que los propios sandinistas. ${ }^{18}$

\footnotetext{
14 Ibídem, p. 132

15 Basta con realizar una búsqueda rápida en Google para obtener información de los escandalosos casos de corrupción que han afectado la política española, entre los que destacan el financiamiento ilegal del Partido Popular y los negociados que enriquecieron aún más a miembros de la familia real española; los bochornosos casos de conflictos de intereses que afectaron los gobiernos de Vicente Fox y Felipe Calderón, en México, o el juicio por enriquecimiento ilícito y corrupción que enfrentó el expresidente Miguel Angel Rodríguez Echeverría, de Costa Rica, considerada por las élites conservadoras nicaragüenses como el paradigma de la democracia en América Latina. 
Los líderes de ambas agrupaciones, Virgilio Godoy y Ramiro Gurdián son, por lo demás, acusados de intolerantes. ${ }^{19}$

En cuando al segundo elemento, en el texto también se insiste reiteradamente en responsabilizar al Frente Sandinista, y particularmente a Daniel Ortega, de todos los males, económicos y sociales que enfrentaba Nicaragua. Así, con el sandinismo "la nación había perdido su cauce", según afirma el banquero Ernesto Fernández en la presentación del volumen. ${ }^{20}$ Durante el sandinismo "la nación nicaragüense [había sido] destruida desde las bases". ${ }^{21} \mathrm{O}$ bien, el país había quedado atrapado "en un atolladero después de la década sandinista" ${ }^{22}$

Referente al tercer elemento de nuestro análisis, la de promover la idea de que se construye una Nicaragua para todos se expresa desde el breve texto introductorio, firmado por la expresidenta

Chamorro. En él, la ex mandataria asegura: "Quise una Nicaragua para todos, una nación de ciudadanos capaces de vivir armoniosamente" ${ }^{23}$. La idea también se repetirá con insistencia en las siguientes páginas. Tras definir al gobierno como "ni contrarrevolucionario ni pro-imperialista", Lacayo asegura que lo que pretendía era que Nicaragua fuera nuevamente de "todos sus hijos" pues "nadie era más hijo de la patria que otro", ${ }^{24}$ omitiendo que el grupo social que llegó al poder con la señora Chamorro había gozado históricamente de derechos sociales, políticos y económicos que estaban vedados para el resto de la población nicaragüense.

\section{La construcción del aura mítica de Violeta Chamorro}

En este discurso, como ya fue indicado $\mathrm{y}$ veremos en los siguientes párrafos, se advierte también la intención de convertir la figura de la señora Chamorro y a su gobierno en una especie de mito político ideológico, en un paradigma de la democracia que debiera ser admirado y seguido por los nicaragüenses.

En su estudio sobre los mitos políticos, Raoul Girardet sostiene que una variante en la que este se presenta es la figura del "salvador" que asume la tarea de salvar a la ciudad, o al país, de las fuerzas perniciosas que le amenazan. ${ }^{25}$ Este héroe salvador, o heroína, asociado a imágenes de luz, libera al pueblo dando "por tierra con los monstruos, hace retroceder a las fuerzas del mal" ${ }^{26}$

Girardet ofrece varios ejemplos de cómo operan este tipo de mitos o mitificación, todos tomados de la política francesa. El que me más me ha llamado la atención es el que se refiere a Antoine Pinay, que detentó el cargo de primer ministro en 1952, transformado por los medios de comunicación y la historiografía en esta suerte de mito. Para ello, reconocidas publicaciones parisinas se encargaron de construir una imagen de este político cercana a la mayoría de los franceses, que compartía las mismas inquietudes, preocupaciones y aspiraciones de la población. Además, se destacaba su origen humilde, pero también su disposición a dar solución a los problemas que aquejaban a todos. Así, la prensa francesa

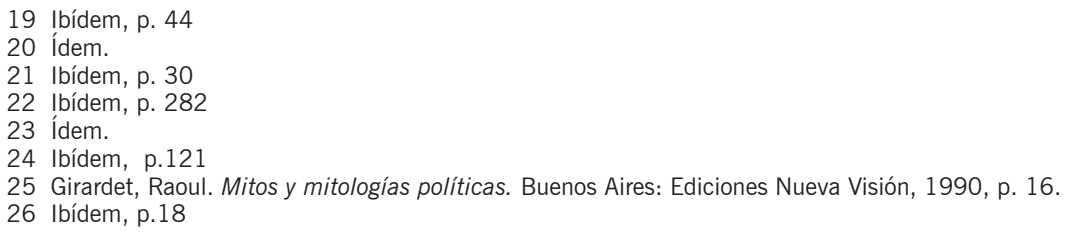


se encargó de divulgar que Pinay era "un hombre cualquiera (...) llamado a resolver la crisis del franco"; de origen modesto, hijo de pequeño industrial y madre de ascendencia campesina. ${ }^{27}$ La revista semanal Paris-Match lo describía como un hombre con "una memoria de ama de casa para el precio del kilo o la librea de lenguado, manteca o espinacas...". ${ }^{28} \mathrm{El}$ propio político abonaba a esa imagen con declaraciones como la siguiente: "La política no es mi fuerte. En eso me parezco a muchos franceses...". ${ }^{29}$ Era pues, un hombre del pueblo, uno francés más, común y corriente que se ponía al frente de su país para sacarlo de la crisis y el caos en que se encontraba. Para, como divulgaban los medios, "volver a poner la casa en orden". 30

Girardet también sostiene que para lograr el proceso de mitificación se da también "un proceso de identificación de un destino individual y un destino colectivo, de todo un pueblo y el intérprete profético de su historia" y que este jefe ya no aparece entonces como el simple representante, el mero ejecutante de la voluntad general. Es su encarnación en el sentido más profundamente religioso del término: encarna en la totalidad de su destino histórico, de su pasado, su presente y su futuro" 31

Aunque en términos geográficos, políticos, sociales, culturales y aún temporales existe una más amplia que el Océano Atlántico entre la realidad y la historia francesa y la nicaragüense, este ejemplo ofrecido por Girardet sirve muy bien para ilustrar y comprender como se da lo que considero la construcción de un "aura mítica" o la mitificación de la expresidenta Chamorro y su gobierno. Cada uno de esos procesos se expresa en las narrativas que estamos analizando, pero se perciben con mayor nitidez en el tercer volumen, que comentaré a continuación.

Editado por Cristiana Chamorro Barrios, hija mayor de la expresidenta, el texto en cuestión más bien semeja un álbum de fotografías familiares. En él se establece un vinculo estrecho y directo entre la historia familiar de la familia Chamorro Barrios con la historia nacional del país. La autora se propone narrar la historia de sus padres, "que es la misma de Nicaragua", ${ }^{32}$ afirmación que si bien se respalda en el destacado papel que ha jugado dicha familia en la política nicaragüense, en cierta forma podría ser interpretada también como una pretensión de privatizar la historia del país. Pues, por otra parte, es una aseveración que también podría ser reclamada por familias que no cuentan con apellidos tan reconocidos, como los habitantes de la costa Caribe, los miembros de las comunidades indígenas o los sectores populares urbanos. ¿Acaso la historia de Nicaragua no es también una historia de represión, de saqueo, de despojo y explotación? ¿Y quién más ha sufrido despojo y explotación que los sectores subalternos?

La editora expresa también que el volumen es resultado de una investigación de más de año y medio en el que se leyeron los editoriales y otros textos escritos por Pedro Joaquín Chamorro en casi tres décadas de vida profesional, de 1949 a 1978, los que se ponen en diálogo o complementan con lo discursos de la señora Chamorro en veintiún años de vida pública (1978-1997).

Este contrapunto da base al argumento de que la historia de la expresidenta es la continuidad de la historia de su esposo,

31 Ibídem, p.76

32 Chamorro Barrios, Cristiana (edit.), La democracia de Pedro y presidenta Violeta B. de Chamorro (Managua: Fundación Violeta B. de Chamorro/Diario La Prensa, 2012),p. 7. 
asesinado en 1978 por un grupo de sicarios contratados por oscuros personajes afines al dictador Somoza. Según Chamorro Barrios, su madre afirma que recogió la bandera de Pedro "para llevar a Nicaragua a la democracia, desde una dictadura de derecha primero, y después desde una dictadura de izquierda". ${ }^{33}$ En esa tarea heroica ambos personajes sacrificaron sus vidas personales por Nicaragua.

Siguiendo esa línea, asegura que el triunfo electoral de la señora Chamorro representa la victoria de los ideales políticos del periodista asesinado. De ahí que también sostenga que con su gobierno sentaron "las bases de lo que debe ser la republica de Nicaragua". ${ }^{34}$ Durante los actos de su campaña presidencial, Violeta anuncia: "queremos fundar una república" y que con su triunfo nacerá "la república" ${ }^{35}$ La idea hace alusión a una frase contenida en uno de los editoriales escritos por Pedro Joaquín Chamorro Cardenal en los años finales del régimen somocista: "Nicaragua volverá a ser república", frase afortunada que se ha repetido reiteradamente en los últimos cuarenta años. En dicho escrito, Chamorro se refiere a la necesidad de "restablecer el funcionamiento efectivo de los tres poderes, independientes el uno del otro; restablecer el derecho del pueblo a darse sus propios gobernantes. La limpieza en el proceso electoral, el entierro definitivo de las ideas dinásticas, la abominación de los caudillismos, de las casta privilegiadas y de los fraudes; y se debe incluir la reestructuración de nuestra justicia, que es quizás la parte más baja de nuestro metro moral" ${ }^{36}$
Es evidente que la alusión que hace el periodista es a la república conservadora, que se refiere a los treinta años en que gobernaron presidentes de esa tendencia política, incluso varios de sus antepasados, a finales del siglo XIX. Este período, que también es recordado y promovido por los sectores conservadores del país como una etapa idílica de la historia nicaragüense porque no hubo reelección, los gobernantes traspasaban pacíficamente la banda presidencial, mantenían un estricto control fiscal y daban muestras de honestidad en sus gestiones, ${ }^{37}$ también representa el momento histórico en que la élite más conservadora y oligárquica del país detentó el poder para sí, en detrimento de las clases subordinadas.

Ese relato idílico olvida que en ese período, para resultar electo a la primer magistratura de país, había que ser poseedor de un capital económico que muy pocos podían acumular. Más aún, que entre los presidentes que se traspasaron el mando, algunos estaban vinculados sanguínea o legalmente $o$ tenían estrechas relaciones de amistad. ${ }^{38}$ Fue también en este mismo período que se dio una de las más fuertes rebeliones indígenas ocurridas en el país, debido al trabajo forzado a que eran sometidos "para llevar el progreso", rebelión que además fue brutalmente aplastada. ${ }^{39}$

Entonces, si el proyecto político de Chamorro Cardenal, pese a las adaptaciones experimentadas por el tiempo en que le correspondió vivir, se inspiraban en los gobiernos oligárquicos de finales del siglo XIX, y si el gobierno de la señora Violeta Chamorro es la realización de éste, el modelo

33 Ibídem, p. 1

34 Lacayo, La difícil transición, p.

35 Chamorro Barrios, La democracia de Pedro..., pp. 209 y 221

36 Chamorro Cardenal, Pedro Joaquín, La patria de Pedro. El pensamiento nicaragüense de Pedro Joaquín Chamorro. Managua: La Prensa, 1981.

37 Ver, por ejemplo, La república conservadora de Nicaragua, 1858-1893. Managua. Fundación Vida. Colección Cultural de Centro América Serie Tesis Doctorales No. 1. 2003

38 Por ejemplo, Fernando Guzmán, que gobernó de 1867 a 1871, y los mandatarios que le sucedieron, Vicente Cuadra (1871-1775) y Pedro Joaquín Chamorro (1875-1879) pertenecían al mismo clan familiar.

39 Ver Téllez, Dora María, iMuera la gobierna...! Colonización en Matagalpa y Jinotega. 1820-1890. Managua: URACCAN, 1999. 
político impuesto en Nicaragua después de 1990 resulta elitista y excluyente, más que democrático. Esto también explicaría la poca sensibilidad mostrada ante el incremento de la pobreza y marginalidad en amplios sectores de la población, resultado de las políticas de ajuste económico que se aplicaron durante su mandato, y la evidente tendencia de su gobierno a cercenar los espacios de participación de las organizaciones populares que cargaron con un enorme peso en sus espaldas, quizás con el principal, en la destrucción de la guardia somocista, la columna vertebral que sostenía al régimen somocista.

Pese a esas duras consecuencias de su plan económico y la poca sensibilidad mostrada frente a los sectores menos protegidos económica y socialmente, el discurso predominante sobre la transición, reiteramos, además de presentar a la señora Chamorro comouna madre para todos los nicaragüenses, y a su gobierno como un gobierno de o para todos, ensalza su figura como un paradigma político a seguir. Esta otra operación, presente en los tres textos comentados, se evidencia en el primero con la colección de frases elogiosas que diversos mandatarios dedicaron a la viuda de Chamorro cuando era presidenta. Así, Chamorro "simboliza la oferta hecha a la reconciliación... el camino de la unidad, la cicatrización de heridas de pasado conflictos", según el rey Juan Carlos, de España. La ex presidenta también, gracias a las palabras del presidente de Corea del Sur, resulta "una de las más brillantes líderes políticas del mundo". Mientras que para el primer presidente Bush, bajo el liderazgo de Chamorro, "las instituciones democráticas empezaron a enraizarse y comenzar a crecer", según las palabras de John Maisto, el embajador estadounidense en Managua. $\mathrm{Y}$ según otros funcionarios diplomáticos,
Barrios viuda de Chamorro era la mujer "más admirada del mundo".

El textoescrito por suministrodela Presidenta, también contribuye a esta operación. Lacayo nos presenta a la señora viuda de Chamorro como una heroína literaria plana, sin complejidad alguna, pero que encarna todas las virtudes positivas que uno pueda imaginarse, ubicándola así en las antípodas de sus adversarios. Estos, en cambio, como el vicepresidente Virgilio Godoy, el actual presidente Ortega y hasta algunos líderes de la empresa privada, son descritos apenas como pequeñas variantes de un mismo polo negativo. Son representaciones maniqueas, en donde todo es blanco o negro. No existen los matices.

Así tenemos que la señora Chamorro, hasta en las más agudas circunstancias, se mantiene serena, actúa de forma firme y a la vez cariñosa, $^{40}$ genera confianza; no se asombra como si de antemano supiera las cosas (por ejemplo, cuando le anunciaron que había ganado las elecciones presidenciales en 1990); ${ }^{41}$ y cuando habla o pronuncia discursos, "los conceptos le salen del corazón" ${ }^{42}$

No faltan imágenes literarias o frases retóricas para potenciar su imagen. Al recorrer el país durante su campaña electoral, Chamorro dejó "una estela de libertad por toda Nicaragua" ${ }^{43}$ Las alusiones y referencias religiosas, que en su momento fueron advertidas durante la campaña electoral, son retomadas también para describirla. Así, Chamorro resulta "una bendición para Nicaragua". Su género resulta un elemento muy conveniente para favorecer esa imagen sin par. Ella misma en determinado momento declara: "No soy política, pero soy mujer", ${ }^{44}$ y esto pareciera que compensara las habilidades políticas necesarias para dirigir el país.

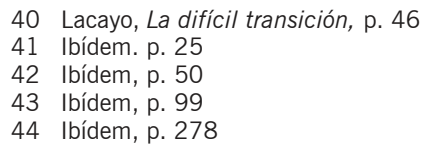


Estas virtudes y habilidades le serán igualmente útiles para alcanzar el objetivo de obtener ayuda económica para el país, pues con ese mismo toque femenino logra convencer de sus necesidades a mandatarios extranjeros. En sus reuniones bilaterales con otros jefes de Estado, Violeta hace gestos coquetos y es risueña; otras veces tiene una risita maliciosa y reparte besos. Además, tiene mucha gracia y se presenta "sumamente elegante", ${ }^{45}$ y hacía gala también de "un candor y una sonrisa que amarraba mandatarios de todo el mundo" ${ }^{46}$

En esta misma secuencia y alcanzando la máxima idealización, para quienes trabajaban para su gobierno y, según Lacayo, para muchos nicaragüenses "Violeta era como una reina"47; y lo más importante, recordemos lo que sostiene Girardet, "no solo representaba [sino que también] encarnaba la democracia". ${ }^{48}$

En el lado opuesto, sus adversarios representaran valores contrarios. Ante los obstáculos que enfrenta la UNO el vicepresidente Godoy luce abatido, temeroso, ${ }^{49}$ otras veces actúa como energúmeno. Mientras que Ortega, el líder del FSLN, resulta inconsistente, como si no supiera qué hacer o qué decir, es confuso, prefiere mantener su influencia sobre sus bases radicalizadas antes que "actuar como estadista".

\section{Crítica a la política de amnesia ¿qué se propone olvidar?}

En relación al gobierno sandinista, lo que el discurso de la transición olvida o ignora abiertamente son las políticas sociales emblemáticas del sandinismo: La distribución de la tierra; reducción de analfabetismo, las guarderías infantiles y el programa de educación de adultos, entre otras.

Olvida además que en un proceso tan complejo como el vivido en Nicaragua después de 1990, para alcanzar la estabilidad política y social que se estableció posteriormente, fue indispensable la buena voluntad de todos los sectores. No se trato de la labor de un solo grupo. La misma reducción y profesionalización de ejército, como puede deducirse del texto de Lacayo, fue obra principalmente de los propios oficiales de la institución. No obstante, ellos no recibirán ningún reconocimiento por su labor.

Chamorro afirma que ella "no quería pasar a la historia como un gobierno que aplasta a los opositores.... [sino uno en el que] el diálogo y las negociaciones suplantaron a las balas..." Pero si alcanzó tal logro, también significa que el sandinismo, a pesar de las llamadas asonadas, también estuvo dispuesto a dialogar y a no recurrir a las balas, contrario de la actitud asumida por los que se opusieron a la revolución.

Si el gobierno de Chamorro no reprimió las protestas populares con mayor vehemencia de lo que lo hizo fue principalmente porque las instituciones armadas creadas por el sandinismo -el ejército y la policía- fueron construidas con una filosofía diferente a la que regía a la Guardia Nacional somocista. Violeta no contaba en sus manos como un aparato represor como lo tuvo Somoza. Este es otro importante aspecto que se deja en el olvido.

En cuanto a la caracterización del proceso democrático que desarrolló el grupo político que encabezó Chamorro, vale la pena retomar 
el término acuñado por Edelberto Torres Rivas, al denominar como "democracias malas" a los procesos políticos y gobiernos surgidos tras la conclusión de los conflicto armados en la región, denominadas así por defraudar las esperanzas de la población o llevarles incertidumbre ${ }^{50}$.

En mi opinión, además de malas, o quizás más que malas, adjetivo que sugiere la idea de deterioro, descomposición o putrefacción, desde una perspectiva de los sectores mayoritario de la población se les describiría bien al calificárseles como "democracias fraudulentas" o "democracias timadoras". Y a diferencia de la idea de democracias malas o que funcionan mal, por su carácter de timadoras las democracia impuestas en la región funcionan perfectamente, como están programadas y se supone deben funcionar. Sus mecanismos funcionan con precisión. Su objetivo es engañar a las mayorías.

Si observamos bien esos mecanismos campañas electorales, promesas de los candidatos, conteo de votos- parecieran diseñados para embaucar al elector. Las campañas presidenciales son diseñadas como espectáculos circenses, con discursos elaborados por algún prestidigitador $\mathrm{o}$ algún encantador cuyo principal objetivo es entretener o adormecer al público con palabras dulces y promesas fantásticas que de antemano saben que no serán cumplidas, pero que resultan útiles para atraer la atención del público, desviar su atención de la gravedad de los verdaderos conflictos y capturar su voluntad electoral. Y por lo visto que ha ocurrido en los dos últimos años en el Estado Español, pareciera que el fenómeno no es privativo de Centroamérica.

En este aspecto, resulta interesante notar, como lo hace David Close, que en 1993, apenas tres años después de haber sido electa la presidenta Chamorro, sólo el $10 \%$ de los nicaragüenses decía sentirse representado por su gobierno. La cifra impacta más si se considera que una encuesta realizada dos años antes, en 1991, el 40\% consideraba que la mandataria les representaba. Mi interpretación de estas variantes es que en la medida en que se asentaba y profundizaba el nuevo proyecto político y su programa económico, que no tomaba en consideración a las clases subalternas y que contrario a lo prometido, este no mejoró las condiciones de vida de las mayorías, estos sectores se dieron cuenta que Chamorro y su gobierno no les representaba ni respondía a sus intereses.

Por esto resulta muy pertinente la pregunta que hace Torres-Rivas en el texto ya citado: $¿$ a más democracia más, pobreza? ${ }^{51}$ Volviendo al caso nicaragüense, la respuesta pareciera ser sí, si tomamos en consideración que durante los años del gobierno de la señora Chamorro, cuando según el discurso que hemos venido comentando, se instaló la democracia en Nicaragua, el $43.6 \%$ de la población en áreas urbanas vivía en condiciones de pobreza extrema. En algunas zonas rurales, la cifra representaba al $78 \%$ de la población. Los más perjudicados por esta situación eran los niños, hecho representado en el incremento de la mortalidad infantil que alcanzó la cifra de 60 por mil nacidos vivos. ${ }^{52}$

Otro dato que "olvida" y no se encontrará en este discurso sobre la democratización nicaragüense, es el del descenso del índice de desarrollo humano, que como bien señala Close, citando informes de la Cepal de 1994, para ese año había decaído a niveles del Iraq derrotado tras la primera guerra del Golfo..$^{53}$ ¿No se habrían sentido estafados los electores nicaragüenses después de haber depositado su voto por la candidata que les

50 Torres-Rivas, Edelberto, "Las democracias malas de Centroamérica", Nueva Sociedad No. 226, marzo-abril de 2010. Disponible en: http://www.nuso.org/upload/articulos/3684_1.pdf Fecha de consulta: Enero 19 de 2015.

51 Ibídem, , p. 54

52 Close, Los años..., p. 225

53 Ibídem, p. 222 
ofrecía "enderezar la economía", acabar con la escasez y fundar una nueva república con paz y prosperidad?

Obviamente no todos experimentaron esa decepción. Una anécdota relatada por Cristiana Chamorro, hija de la expresidenta Chamorro, cuenta que al final del período del gobierno de su madre, un empresario se le acercó para agradecerle y felicitarle porque la expresidenta les había regresado el país. La escena resume otra parte de la realidad vivida con la transición y democratización de Nicaragua, y resume un significado que no siempre se expresa claramente: con Chamorro regresó a este sector, el sector de los grandes empresarios y las clases adineradas, el país que les había sido confiscado por el sandinismo. Y este también es el verdadero significado del discurso acerca de la "Nicaragua para todos".

\section{A modo de conclusión}

Para concluir, solo quisiera señalar que no se trata de repetir verdades que para muchos ya son bien conocidas, y mucho menos hacer una defensa cerrada del régimen sandinista. Lo que esta crítica ha pretendido es exponer a la luz el sesgo políticoideológico, claramente antisandinista, de estas versiones e interpretaciones del pasado reciente de Nicaragua, que por ahora son las predominantes en Nicaragua.

Este discurso, que como se vea resulta polarizado, pone en entredicho la propia política de reconciliación impulsada por la señora Chamorro, catalogado también como uno de los principales logros y la mejor herencia de sus seis años de gobierno de Chamorro.

Por lo demás tampoco contribuye a la construccióndeundiscursohistóricoriguroso, ni siquiera mínimamente balanceado, ni a la formación de una conciencia y una identidad histórica que contribuya a la unidad de la nación, el principal propósito que motivó a la señora Chamorro, según sus propias palabras, a aceptar la candidatura que la llevó a la presidencia de la república.

\section{Referencias Bibliográficas}

Close, David, Los años de doña Violeta. Historia de la transición política. Managua: Grupo Editorial Lea, 1995. La primera edición, publicada en inglés, es de 1999.

Cruz, Arturo, La república conservadora de Nicaragua, 1858-1893. Managua: Fundación Vida. Colección Cultural de Centro América Serie Tesis Doctorales No. 1. 2003

Chamorro Barrios, Cristiana (edit.), La democracia de Pedro y presidenta Violeta $B$. de Chamorro Managua: Fundación Violeta B. de Chamorro/Diario La Prensa, 2012.

Chamorro Barrios, Pedro Joaquín (edit.). Transición y transformación. 19901996. Imágenes del cambio. Managua: Gobierno de Nicaragua y Editorial El Amanecer, 1996.

Chamorro Cardenal, Pedro Joaquín, La patria de Pedro. El pensamiento nicaragüense de Pedro Joaquin Chamorro. Managua: La Prensa, 1981.

Font, Joan y Ricard Gomá, "El proceso de democratización en Nicaragua: Actores, estrategias y conflicto", en RevistaCIDOB d'Afers Internacionals, No. 20 (1991) Disponible en: http://www. raco.cat/index.php/revistacidob/ article/viewFile/27849/51977

Fecha de consulta: Enero 22 de 2015

Ogarrio Badillo, Gustavo, Breve historia de la transición y el olvido. Una lectura de la democratización en América Latina. México: Ediciones EON y CIALCUNAM, 2012.

Renzi, María Rosa y Agurto, Sonia (edits.), ¿Qué hace la mujer nicaragüense ante la crisis económica? Managua: FIDEG, 1992. 
Rovira Más, Jorge, "Transición a la democracia y su consolidación en Centroamérica: Un enfoque para su análisis", en Anuario de Estudios Centroamericanos, No. 1-2, Vol. 2 (2002), pp. 9-56.

Rovira Más, Jorge, "Nicaragua 19792000. Transición a la democracia y perspectivas de su consolidación", en Revista Encuentro No. 82 (2009).

Disponible en: http:/ / encuentro.uca.edu.ni/ images/stories/2012/pdf/82e/82e1a. pdf
Fecha de consulta: Enero 7 de 2015.

Téllez, Dora María, ¡Muera la gobierna...! Colonización en Matagalpa y Jinotega. 1820-1890. Managua: URACCAN, 1999.

Torres-Rivas, Edelberto, "Las democracias malas de Centroamérica", Nueva Sociedad No. 226, marzo-abril de 2010. Disponible en: http:/ / www.nuso.org/ upload/articulos/3684_1.pdf

Fecha de consulta: Enero 19 de 2015. 